\title{
SURVEI EFIKASI DIRI MAHASISWA PRODI PENDIDIKAN AKUNTANSI PADA MASA PEMBELAJARAN JARAK JAUH
}

\author{
Yolandaru Septiana \\ Universitas Negeri Yogyakarta, Indonesia \\ yolandaru.septiana@uny.ac.id
}

\begin{abstract}
Abstrak: Pembelajaran jarak jauh di era pandemi Covid-19 memberikan kesempatan untuk belajar mandiri dan hasil belajar mahasiswa tetap meningkat. Hasil belajar dapat ditingkatkan salah satunya melalui peningkatan efikasi diri. Studi ini bertujuan untuk mengetahui efikasi diri mahasiswa Prodi Pendidikan Akuntansi pada masa pembelajaran jarak jauh. Penelitian ini merupakan penelitian survei. Responden penelitian ini adalah 134 mahasiswa Prodi Pendidikan Akuntansi angkatan 2017-2019. Teknik pengambilan sampel penelitian ini adalah proportionate stratified random sampling technique. Instrumen yang digunakan adalah angket yang dikembangkan oleh S Schmitz (2013), terdiri dari 4 komponen yaitu kinerja akademik, pengembangan pengetahuan dan keterampilan, interaksi sosial dengan fakultas, dan mengatasi stres akademik. Hasil penelitian ini menunjukkan bahwa efikasi diri mahasiswa Prodi Pendidikan Akuntansi pada masa pembelajaran jarak jauh adalah baik.
\end{abstract}

Kata kunci: Efikasi Diri, Pendidikan Akuntansi, Pembelajaran Jarak Jauh

\section{SELF EFFICACY SURVEY OF ACCOUNTING EDUCATION STUDY PROGRAM STUDENTS IN THE DISTANCE LEARNING PERIOD}

\begin{abstract}
Distance learning in the Covid-19 pandemic era provides opportunities for independent study and increase learning outcomes. One of the learning outcomes can be improved by increasing self-efficacy. This study aims to determine the self-efficacy of Accounting Education Study Program students during distance learning. This research is survey research. The respondents of this study were 134 students of the Accounting Education Study Program class of 2017-2019. The sampling technique for this research was a proportionate stratified random sampling technique. The instrument used was a questionnaire developed by S Schmitz (2013), consists of 4 components, namely academic performance, development of knowledge and skills, social interaction with faculty, and coping with academic stress. The results of this study indicate that the self-efficacy of the Accounting Education Study Program students during distance learning is good.
\end{abstract}

Keywords: Self-Efficacy, Accounting Education, Distance Learning

\section{PENDAHULUAN}

The World Health Organization (WHO) telah mengumumkan bahwa wabah Covid-19 merupakan pandemi global (Cucinotta \& Vanelli, 2020). Pandemi Covid-19 memberikan dampak di seluruh sektor kehidupan. Masyarakat diminta untuk menerapkan protokol kesehatan dalam beraktivitas sehari hari. Pemerintah mengeluarkan kebijakan new normal yaitu masyarakat dapat hidup berdampingan dengan pandemi Covid-19 dengan tetap mematuhi protokol kesehatan (Rafsanjani, 2019). Protokol kesehatan meliputi menggunakan masker, menjaga jarak, mencuci tangan, dan menghindari kerumuman. Tujuan adanya protokol kesehatan untuk mengurangi penyebaran virus Covid-19. Di masa pandemi ini akses masyarakat untuk beraktivitas menjadi terbatas dan harus beradaptasi dengan kebiasaan normal baru (new normal). 
Salah satu bidang kehidupan yang terdampak Covid-19 adalah bidang pendidikan. Kebijakan pendidikan di era pandemi ini adalah menyelenggarakan pembelajaran online atau pembelajaran jarak jauh (Rafsanjani, 2019). Kegiatan pembelajaran mulai SD hingga Perguruan Tinggi diarahkan untuk diselenggarakan dengan pembelajaran jarak jauh. Pendidikan jarak jauh merupakan pembelajaran dengan tatap muka tidak langsung yang menggunakan media untuk interaksi pendidik dan peserta didik (Prawiyogi et al., 2020). Peserta didik belajar dari rumah kemudian guru memfasilitasi kegiatan belajar secara online learning. Faktor yang perlu diperhatikan dalam pembelajaran jarak jauh adalah perhatian, percaya diri pendidik, pengalaman, mudah menggunakan peralatan, kreatif menggunakan alat, dan menjalin interaksi dengan peserta didik (Prawiyogi et al., 2020). Kelemahan pembelajaran jarak jauh meliputi akses listrik yang bisa padam, kekuatan jaringan internet, komitmen orang tua dan peserta didik, dan kemajuan belajar peserta didik (Prawiyogi et al., 2020). Tantangan pembelajaran jarak jauh ini dapat berupa lemahnya pengawasan terhadap mahasiswa, jaringan internet di daerah pelosok, dan mahalnya biaya kuota (Sadikin \& Hamidah, 2019). Pembelajaran jarak jauh di tingkat universitas diselenggarakan dengan berbagai platforms meliputi menggunakan learning management system (LMS), aplikasi, website, dan media sosial (Gunawan; Ni Made Yeni Suranti; Fathoroni, 2020). Banyak pendidik yang menggunakan aplikasi WhatsApp dan media sosial lainnya (Gunawan; Ni Made Yeni Suranti; Fathoroni, 2020). Platforms lain yang bisa digunakan meliputi google classroom, WhatsApp group, zoom meeting, dan lain-lain.

Efektivitas pembelajaran daring pada penelitian yang dilakukan Widiyono (2020) adalah mahasiswa mengikuti kuliah daring menggunakan hp dengan sinyal internet yang baik, tetapi mahasiswa kurang memahami materi dan banyak tugas sehingga pembelajaran kurang efektif. Namun hasil penelitian tersebut berbeda dengan studi yang dilakukan Hariani et al., (2020) menunjukkan bahwa tingkat pemahaman mahasiswa Prodi Pendidikan Akuntansi terhadap pemanfaatan e-learning sebagai media pembelajaran jarak jauh sebanyak $70 \%$, tingkat kesediaan untuk melanjutkan pemanfaatan e-learning secara utuh sebanyak $25 \%$, serta tingkat kebutuhan terhadap kehadiran dosen secara real sebanyak 100\%. Perbedaan aspek pemahaman mahasiswa ini terjadi karena situasi, kondisi, sarana, dan prasarana yang dialami berbeda.

Pembelajaran jarak jauh ini memberi kesempatan bagi mahasiswa untuk belajar mandiri. Selain itu mahasiswa perlu meningkatkan motivasi belajar dan efikasi diri untuk meningkatkan hasil belajarnya. Hal tersebut karena hasil belajar dapat ditingkatkan melalui peningkatan efikasi diri dan motivasi belajar (Gunawan; Ni Made Yeni Suranti; Fathoroni, 2020). Efikasi diri merupakan keyakinan individu terhadap kemampuannya untuk melakukan tindakan yang diberikan kepadanya (Schunk, 1991). Pada masa pembelajaran online, terdapat computer self-efficacy, Internet and information-seeking self-efficacy and LMS (Learning Management Systems) self-efficacy (Alqurashi, 2016). Efikasi diri tidak hanya memberikan pengaruh pada perilaku (Schunk, 1991). Efikasi diri mendorong peserta didik untuk lebih percaya diri dan mandiri (Prior et al., 2016a). 
Berbagai faktor yang mempengaruhi efikasi diri dalam pembelajaran online meliputi pengetahuan dan pengalaman pembelajaran online, masukan dan pengahrgaa, interaksi dan komunikasi online, pengaruh social, sikap dan motivasi peserta didik (Peechapol et al., n.d.). Efikasi diri erat kaitannya dengan kinerja akademik peserta didik. Semakin tinggi skor efikasi diri peserta didik sejalan dengan semakin tinggi tingkat kinerja akademik peserta didik (Yokoyama, 2019).

Efikasi diri berkaitan dengan keyakinan orang terhadap kemampuannya untuk memengaruhi peristiwa yang berkaitan dengan kehidupan mereka (Bandura, 2010). Sumber informasi dalam efikasi diri meliputi pengalaman kemampuan/penguasaan, pemodelan sosial, persuasi sosial, persepsi reaksi emosional dan fisik (sumber). Pengalaman kemampuan dibutuhkan dalam mengembangkan efikasi diri mahasiswa. Oleh karena itu, penting membangun keyakinan pada dirinya agar mendorong kemajuan dalam dirinya. Pemodelan sosial adalah memahami role model untuknya, yaitu melihat orang yang mirip dengannya berhasil, sehingga meningkatkan keyakinan pada kemampuan diri mahasiwa. Selanjutnya persuasi sosial ini erat hubungannya dengan aktivitas sosial sekitarnya terkait keadaan fisiologis dan suasana hati saat menilai kemampuannya. Selanjutnya, persepsi reaksi emosional dan fisik adalah dengan meningkatkan kekuatan fisik dan stamina, mengurangi stres, depresi, dan memperbaiki kondisi emosi dan fisiknya. Efikasi diri memberikan kontribusi pada perkembangan dan fungsi kognitif, serta memberikan pengaruhnya melalui empat proses utama yaitu kognitif, motivasi, afektif, dan proses seleksi (Bandura, 1993).

Studi yang dilakukan Yokoyama (2019) menjelaskan bahwa efikasi diri mempunyai hubungan terhadap kinerja akademik di pembelajaran online. Faktor yang berhubungan dengan hasil pembelajaran online adalah nilai tugas, tujuan mastery-approach dan motivasi intrinsik. kemampuan verbal, tingkat pendidikan, pencarian bantuan, ancaman, strategi pembelajaran mandiri, penggunaan strategi kognitif, waktu masuk, aturan, kepuasan, dan ketekunan. Hasil studi yang dilakukan Prior et al., (2016) menunjukkan bahwa pengaruh efikasi diri pada 3 hal perilaku belajar yang penting meliputi keterlibatan rekan sebaya, interaksi di sistem manajemen pembelajaran (learning management system/LMS) dan interaksi dosen. Hasil temuan terhadap survey online di 151 mahasiswa doktoral bidang bisnis menunjukkan bahwa perilaku mahasiswa dan literasi digital yang positif memberikan kontribusi efikasi diri yang signifikan. Kemudian efikasi diri mempunyai pengaruh positif terhadap keterlibatan rekan sebaya, interaksi LMS, dan interaksi dosen (Prior et al., 2016).

Pembelajaran jarak jauh ini diterapkan di seluruh sekolah dan perguruan tinggi salah satunya di Prodi Pendidikan Akuntansi FE UNY. Pelaksanakan pembelajaran daring dapat dilakukan melalui LMS Besmart atau platforms lainnya disesuaikan dengan kesepakatan dosen dan mahasiswa. Selama pembelajaran jarak jauh ini diterapkan belum ada penelitian yang membahas mengenai efikasi diri mahasiswa Prodi Pendidikan Akuntansi FE UNY pada masa pembelajaran jarak jauh. Survei efikasi diri mahasiswa di masa pembelajaran jarak jauh ini perlu dilakukan supaya mahasiswa dapat mengetahui keyakinan akan kemampuannya dalam mengerjakan 
sesuatu untuk mencapai kecakapan/keahlian tertentu. Kemudian, dosen dapat mengetahui tingkat efikasi diri mahasiswa pada masa pembelajaran jarak jauh. Hal itu supaya dosen dapat meningkatkan kualitas pembelajaran untuk mendorong efikasi diri mahasiswa. Tujuan penelitian ini adalah untuk mengetahui efikasi diri dari mahasiswa prodi Pendidikan akuntansi pada masa pembelajaran jarak jauh. Komponen efikasi diri dalam penelitian ini meliputi kinerja akademik, pengembangan pengetahuan dan keterampilan, interasksi sosial dengan fakultas, dan mengatasi stres akademik.

\section{METODE}

Penelitian ini merupakan penelitian survei untuk mengetahui efikasi diri mahasiswa Prodi Pendidikan Akuntansi pada masa pembelajaran jarak jauh. Efikasi diri mahasiswa Prodi Pendidikan Akuntansi merupakan suatu keyakinan mahasiswa Prodi Pendidikan Akuntansi tentang kemampuannya dalam mengorganisasi tugas, mencapai tujuan, menghasilkan sesuatu, dan mengimplementasikan tindakan untuk mencapai keahlian tertentu. Pendekatan penelitian ini adalah pendekatan kuantitatif. Pelaksanaan penelitian ini pada bulan Juli 2020. Dalam penelitian ini, peneliti menggunakan instrumen angket untuk mengumpulkan data responden penelitian. Butir angket yang digunakan dalam penelitian ini adalah butir angket yang sudah dikembangkan oleh S Schmitz (2013), dimana terdiri dari 4 komponen yaitu kinerja akademik, pengembangan pengetahuan dan keterampilan, interaksi sosial dengan fakultas, dan mengatasi stres akademik. Populasi penelitian ini adalah 201 mahasiswa Prodi Pendidikan Akuntansi FE UNY Angkatan 2017-2019. Teknik pengambilan sampel penelitian ini adalah proportionate stratified random sampling technique. Sampel penelitian ini adalah 134 mahasiswa dengan perhitungan.

Tabel 1. Jumlah populasi penelitian

\begin{tabular}{cc}
\hline Angkatan & Total \\
\hline 2017 & 65 \\
2018 & 72 \\
2019 & 64 \\
Jumlah & 201 \\
\hline
\end{tabular}

Dengan menggunakan rumus Slovin, sampel penelitian ini adalah:

$$
\begin{aligned}
n & =\frac{N}{1+N e^{2}} \\
& =\frac{201}{1+201(0,05)^{2}} \\
& =133,78 \cong 134 \text { mahasiswa }
\end{aligned}
$$


Tabel 2. Perhitungan sampel penelitian

\begin{tabular}{clc}
\hline Angkatan & \multicolumn{1}{c}{ Perhitungan } & Sampel \\
\hline 2017 & $\frac{134}{201} \times 65=43,33 \cong 43$ & 43 \\
2018 & $\frac{134}{201} \times 72=48 \cong 48$ & 48 \\
2019 & $\frac{134}{201} \times 64=42,67 \cong 43$ & 43 \\
\hline
\end{tabular}

Teknik analisis data penelitian ini adalah teknik deskriptif kuantitatif dengan menganalisis hasil respon dari instrumen angket.

\section{HASIL DAN PEMBAHASAN}

Berikut ini hasil penelitian survei efikasi diri mahasiswa Prodi Pendidikan Akuntansi pada masa pembelajaran jarak jauh.

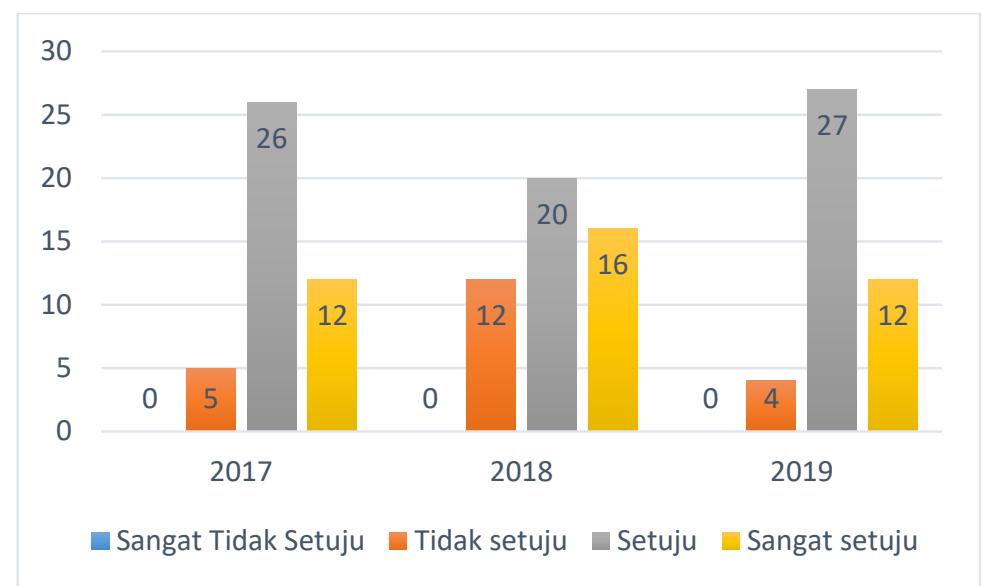

\section{Gambar 1. Diagram Mahasiswa Percaya dapat Mempelajari Semua Materi Kuliah Walaupun Sulit}

Berdasarkan Gambar 1 tersebut dapat diketahui bahwa mayoritas mahasiswa yakin dapat berhasil mempelajari semua materi kuliah walaupun sulit. Mahasiswa Angkatan 2017 berjumlah 26 orang menyatakan setuju dan 12 orang menyatakan sangat setuju. Mahasiswa Angkatan 2018 berjumlah 20 orang menyatakan setuju dan 16 orang menyatakan sangat setuju. Mahasiswa Angkatan 2019 berjumlah 27 orang menyatakan setuju dan 12 orang menyatakan sangat setuju. Keyakinan tersebut didukung dengan adanya rasa semangat, niat belajar, dan usaha yang maksimal. Di era pandemi ini, mahasiswa dituntut untuk lebih aktif belajar. Pembelajaran jarak jauh bukan menjadi faktor penghambat dalam studi ini. 


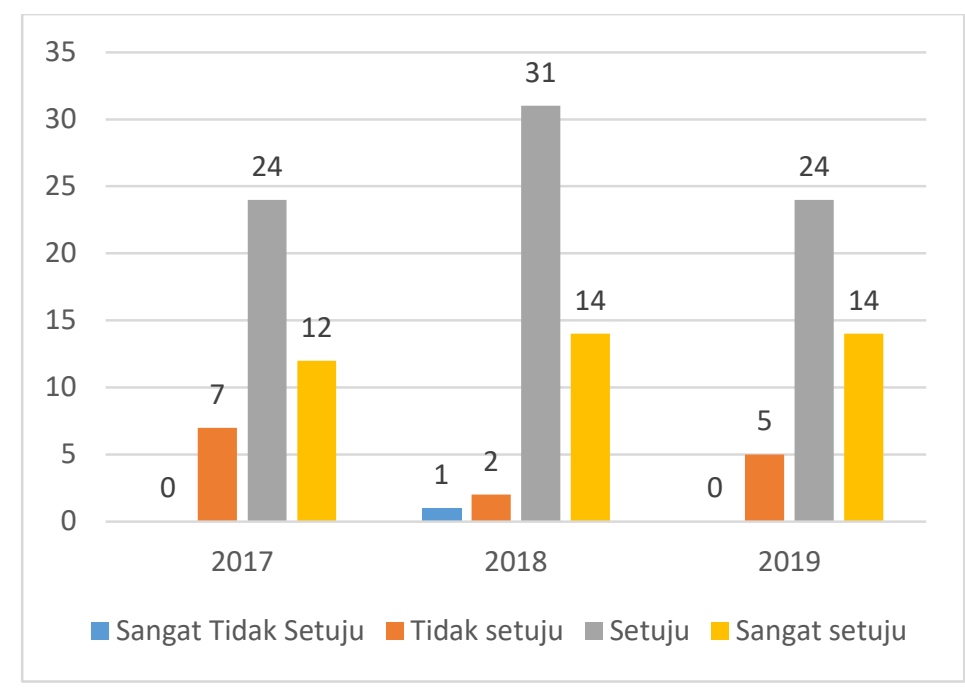

\section{Gambar 2. Diagram Mahasiswa Dapat Mempertahankan Sikap Positif Terhadap Kuliah}

Berdasarkan Gambar 2 tersebut dapat diketahui bahwa mayoritas mahasiswa mampu mempertahankan sikap positif terhadap kuliah bahkan saat ketegangan muncul. Mahasiswa Angkatan 2017 berjumlah 24 orang menyatakan setuju dan 12 orang menyatakan sangat setuju. Mahasiswa angkatan 2018 berjumlah 31 orang menyatakan setuju dan 14 orang menyatakan sangat setuju. Mahasiswa Angkatan 2019 berjumlah 24 orang menyatakan setuju dan 14 orang menyatakan sangat setuju. Terdapat beberapa mahasiswa yang tidak setuju dalam hal mempertahankan sikap positif tersebut. Hal itu terjadi karena ada mahasiswa ketika dalam belajar merasa tegang kemudian mahasiswa tidak bisa bersikap positif artinya mahasiswa merasa sulit dan ingin menyerah, pada era pandemic ini sikap positif perlu ditingkatkan karena proses pembelajaran jarak jauh yang sekaranhg dilakukan membutuhkan kemandirian belajar dan sikap positif untuk terus belajar walaupun di rumah.

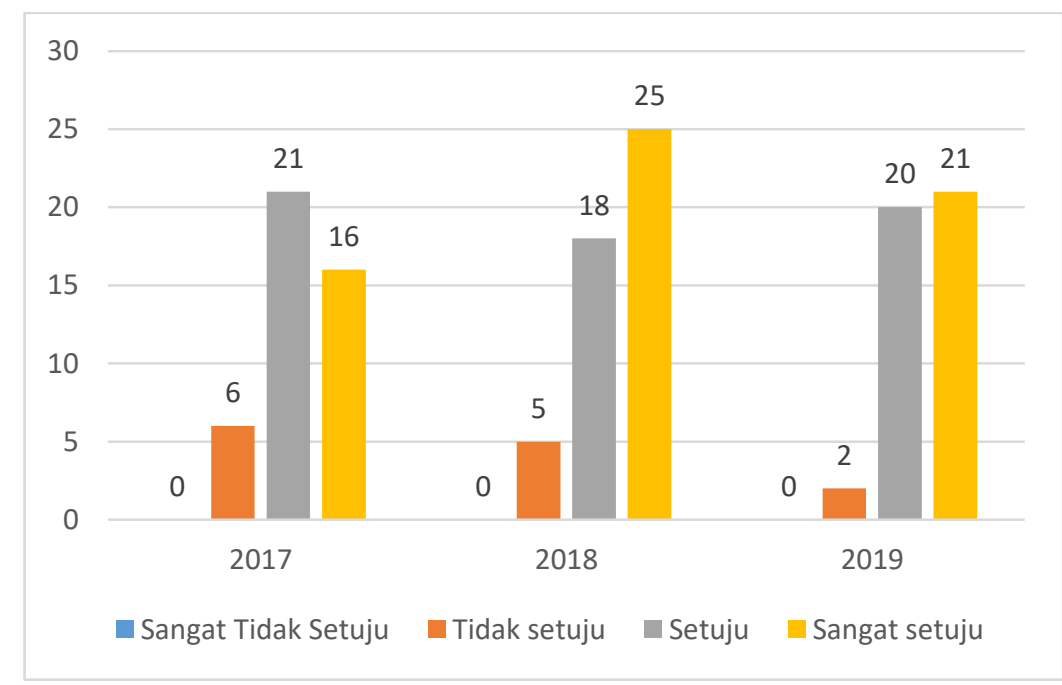

Gambar 3. Diagram Mahasiswa Dapat Mempelajari Materi Kuliah Dengan Berusaha Sangat Keras 
Gambar 3 menunjukkan bahwa dengan berusaha sangat keras atau maksimal, mahasiswa dapat mempelajari materi kuliah bahkan yang paling sulit. Mahasiswa Angkatan 2017 berjumlah 21 orang menyatakan setuju dan 16 orang menyatakan sangat setuju. Mahasiswa Angkatan 2018 berjumlah 18 orang menyatakan setuju dan 25 orang menyatakan sangat setuju. Mahasiswa Angkatan 2019 berjumlah 20 orang menyatakan setuju dan 21orang menyatakan sangat setuju. Salah satu aspek efikasi diri mahasiswa yaitu berusaha maksimal. Mahasiswa dapat berusaha semaksimal mungkin dalam mempelajari materi kuliah. Usaha maksimal ini tentu memberikan dampak positif terlebih di masa pandemi ini. Pembelajaran jarak jauh memberikan stimulus bagi mahasiswa untuk berusaha maksimal dalam mempelajari materi kuliah. Mahasiswa juga terlibat aktif dalam online learning.

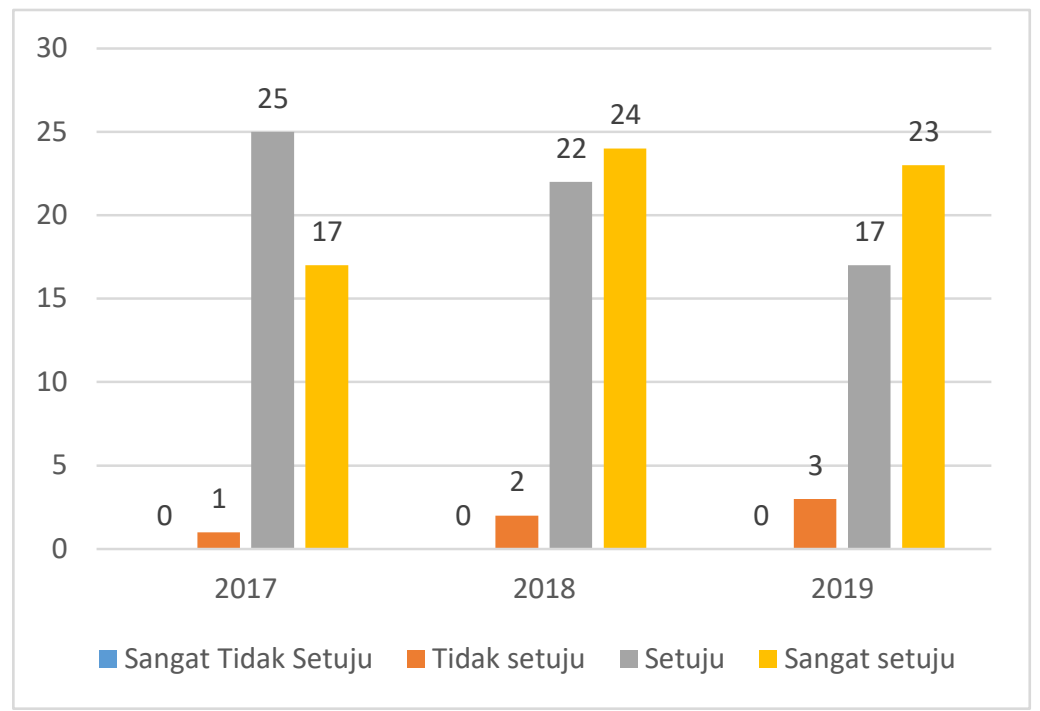

\section{Gambar 4. Diagram Mahasiswa Yakin dengan Berjalannya Waktu Akan Semakin Mampu Mempelajari Materi Kuliah}

Berdasarkan Gambar 4 dapat diketahui bahwa mayoritas mahasiswa yakin dengan berjalannya waktu akan semakin mampu mempelajari materi kuliah. Mahasiswa Angkatan 2017 berjumlah 25 orang menyatakan setuju dan 17 orang menyatakan sangat setuju. Mahasiswa Angkatan 2018 berjumlah 22 orang menyatakan setuju dan 24 orang menyatakan sangat setuju. Mahasiswa Angkatan 2019 berjumlah 17 orang menyatakan setuju dan 23 orang menyatakan sangat setuju. Keyakinan tersebut dilatarbelakangi bahwa dengan semakin berjalannya waktu, mahasiswa semakin memahami bahwa belajar merupakan suatu kebutuhan. Sehingga mahasiswa yakin bahwa akan semakin memahami materi kuliah. Rasa optimisme ini sangat dibutuhkan pada pembelajaran jarak jauh di masa pandemi ini. Rasa optimisme perlu ditingkatkan agar mahasiswa selalu optimis mempelajari materi kuliah dalam situasi dan kondisi apapun. 


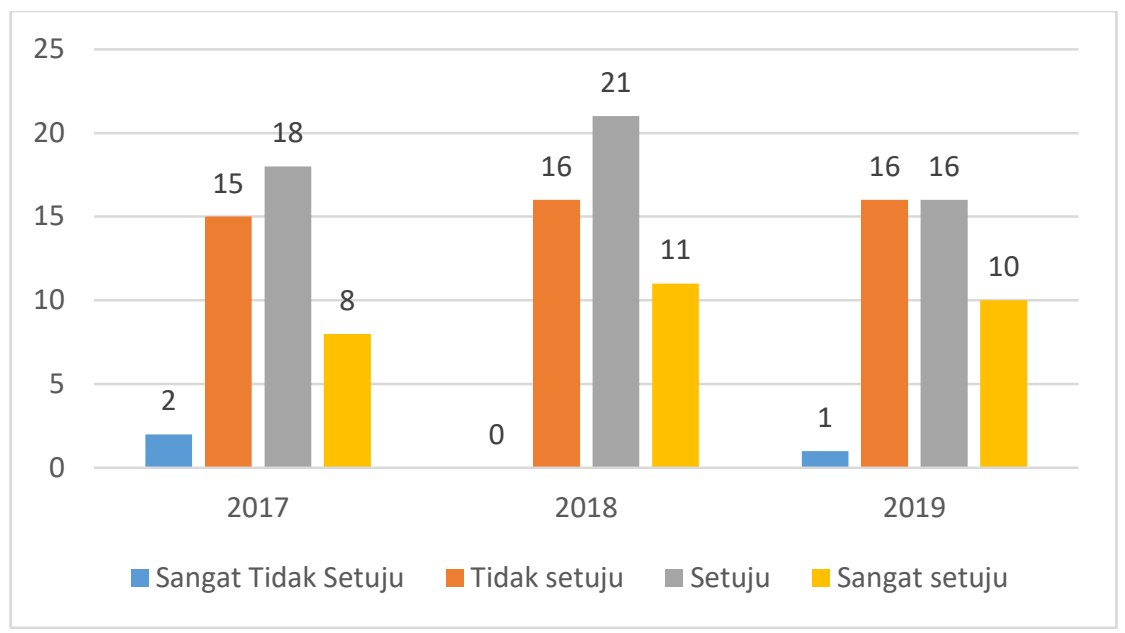

\section{Gambar 5. Diagram Mahasiswa Yakin Dapat Terus Belajar Walaupun Terganggu Di Dalam Kelas}

Gambar 5 tersebut menunjukkan bahwa rata-rata mahasiswa yakin dapat terus belajar walaupun terganggu di dalam kelas. Mahasiswa Angkatan 2017 berjumlah 18 orang menyatakan setuju dan 8 orang menyatakan sangat setuju. Mahasiswa Angkatan 2018 berjumlah 21 orang menyatakan setuju dan 11 orang menyatakan sangat setuju. Mahasiswa Angkatan 2019 berjumlah 16 orang menyatakan setuju dan 10 orang menyatakan sangat setuju. Namun, mahasiswa angkatan 2017 berjumlah 15 orang menyatakan tidak setuju dan 2 orang menyatakan sangat tidak setuju. Mahasiswa Angkatan 2018 berjumlah 16 orang menyatakan tidak setuju. Mahasiswa Angkatan 2019 berjumlah 16 orang menyatakan tidak setuju dan 1 orang menyatakan sangat tidak setuju. Oleh karena itu, dapat diambil kesimpulan bahwa rata-rata mahasiswa yakin dapat belajar saat terganggu di kelas, dan rata-rata menjawab tidak dapat belajar jika ada gangguan di kelas. Hal tersebut dapat terjadi karena setiap individu ada yang mampu belajar saat ada gangguan di dalam kelas dengan tetap belajar, ada yang perlu adaptasi. Ganguan dalam kelas di pembelajaran jarak jauh ini meliputi: jaringan internet, kualitas suara, dan suasana pembelajaran.

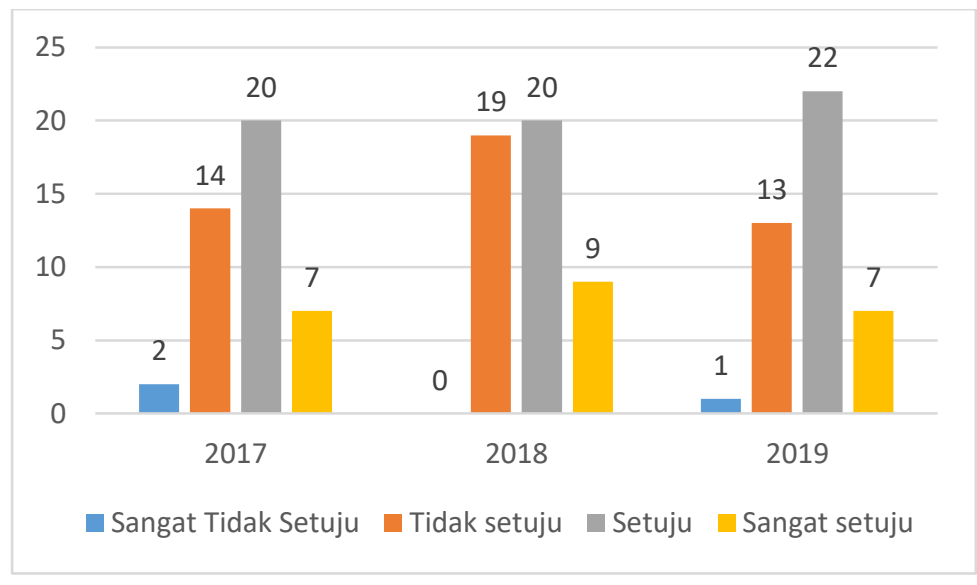

Gambar 6. Diagram Mahasiswa Yakin dapat Mempelajari Semua Materi Kuliah Walaupun Sulit 
Berdasarkan Gambar 6 dapat diketahui bahwa rata-rata mahasiswa yakin dengan kemampuan belajar bahkan saat mengalami hari yang buruk. Mahasiswa Angkatan 2017 berjumlah 20 orang menyatakan setuju dan 7 orang menyatakan sangat setuju. Mahasiswa Angkatan 2018 berjumlah 20 orang menyatakan setuju dan 9 orang menyatakan sangat setuju. Mahasiswa Angkatan 2019 berjumlah 22 orang menyatakan setuju dan 7 orang menyatakan sangat setuju. Namun, mahasiswa angkatan 2017 berjumlah 14 orang menyatakan tidak setuju dan 2 orang menyatakan sangat tidak setuju. Mahasiswa Angkatan 2018 berjumlah 19 orang menyatakan tidak setuju. Mahasiswa Angkatan 2019 berjumlah 13 orang menyatakan tidak setuju dan 1 orang menyatakan sangat tidak setuju. Oleh karena itu, faktor mahasiswa tidak mampu belajar saat mengalami hal buruk adalah faktor psikologis. Setiap hari yang dilalui oleh mahasiswa tentu beragam, ada yang mengalami hari yang buruk juga. Mahasiswa diharapkan kedepannya dapat menjaga kestabilan emosi dan psikis dalam belajar. Kondisi seperti ini diperlukan pada kondisi pandemic dimana setiap kegiatan dilaksanakan dengan akses terbatas.

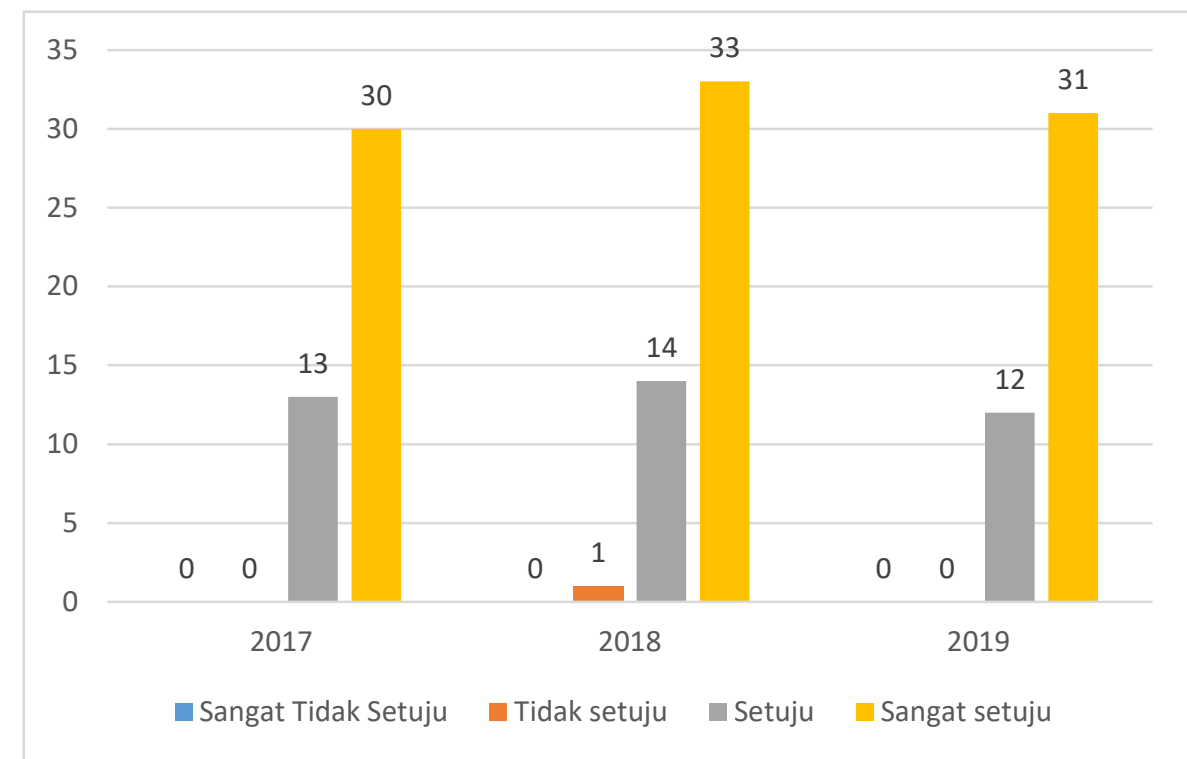

Gambar 7. Diagram Mahasiswa Dapat Mencapai Tujuan Akademik Yang Diinginkan Dengan Berusaha Keras

Gambar 7 menunjukkan bahwa mayoritas mahasiswa dapat mencapai tujuan akademik dengan berusaha keras. Mahasiswa Angkatan 2017 berjumlah 13 orang menyatakan setuju dan 30 orang menyatakan sangat setuju. Mahasiswa Angkatan 2018 berjumlah 14 orang menyatakan setuju dan 33 orang menyatakan sangat setuju. Mahasiswa Angkatan 2019 berjumlah 12 orang menyatakan setuju dan 31 orang menyatakan sangat setuju. Mahasiswa yang memiliki efikasi diri yang baik tentu dapat menentukan tujuan akademik yang diinginkan. Untuk mencapai tujuan tersebut maka diperlukan adanya usaha keras. Mahasiswa punya keinginan untuk mencapai tujuan akademik walaupun di masa pandemic dengan menggunakan pembelajaran jarak jauh. 


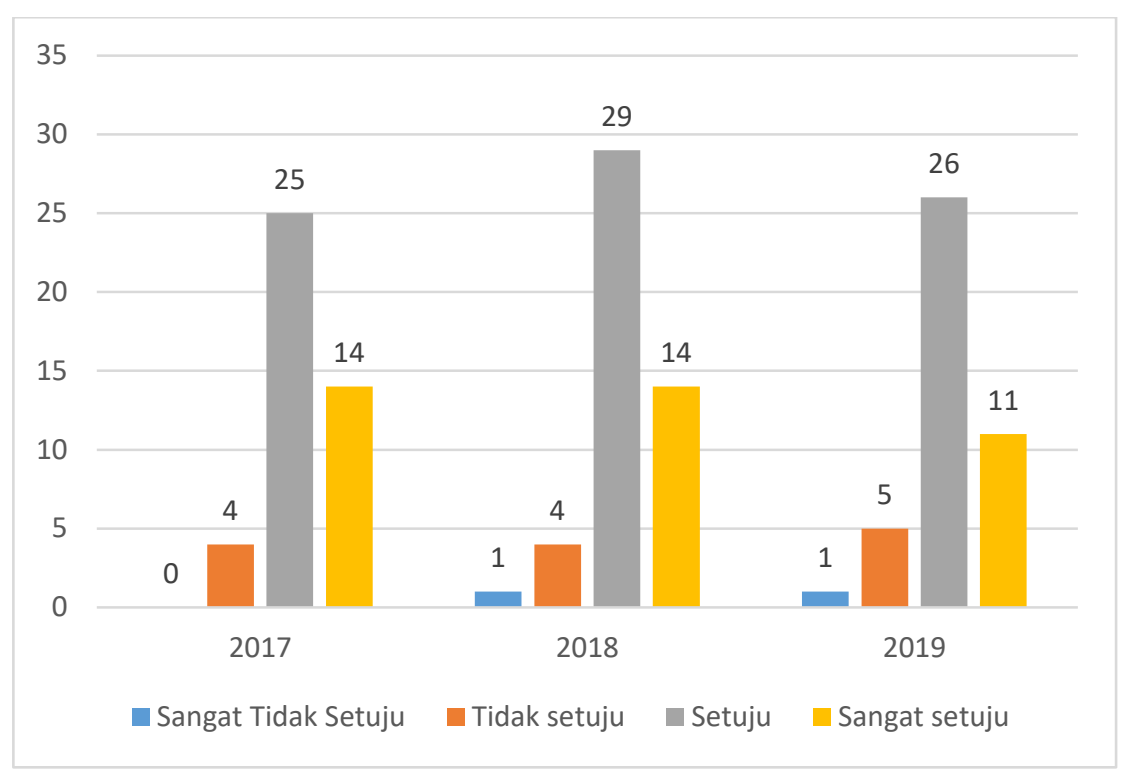

\section{Gambar 8. Diagram Mahasiswa Yakin Mampu Mengembangkan Cara-Cara Kreatif Untuk Mengatasi Stres Yang Terjadi Di Kuliah}

Gambar 8 menunjukkan bahwa mayoritas mahasiswa yakin mampu mengembangkan cara kreatif untuk mengatasi stres saat kuliah. Mahasiswa Angkatan 2017 berjumlah 25 orang menyatakan setuju dan 14 orang menyatakan sangat setuju. Mahasiswa Angkatan 2018 berjumlah 29 orang menyatakan setuju dan 14 orang menyatakan sangat setuju. Mahasiswa Angkatan 2019 berjumlah 26 orang menyatakan setuju dan 11 orang menyatakan sangat setuju. Kegiatan kreatif perlu dilakukan sebagai upaya mengurangi stres saat kuliah. Mahasiswa mengembangkan cara kreatif bermacam-macam untuk mengatasi stres saat kuliah. Pembelajaran jarak jauh tentu mempunyai tantangan tersendiri karena mahasiswa akan disibukkan kegiatan di depan PC atau laptop untuk mengakses materi kuliah. Hal tersebut bisa menimbulkan stres, untuk mengatasinya mahasiswa dapat mendengarkan musik, membuat permainan, mengakses media sosial, dan cara yang lain. 


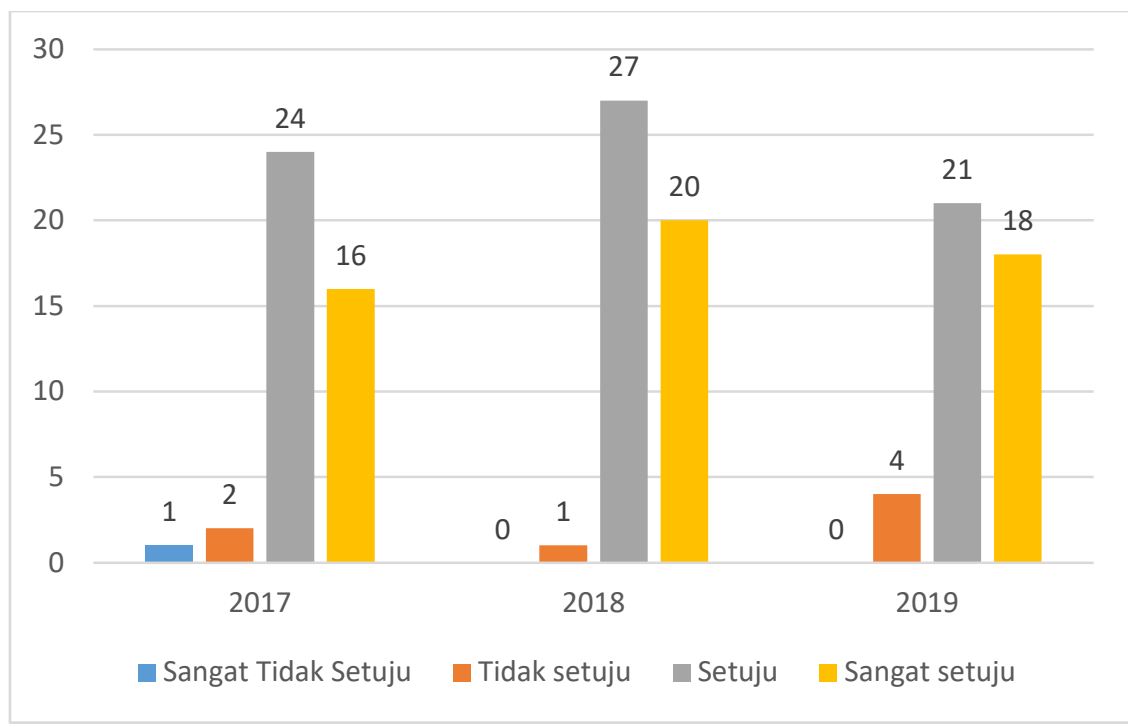

\section{Gambar 9. Diagram Mahasiswa Tetap Termotivasi Untuk Berpartisipasi Aktif dalam Kuliah}

Berdasarkan gambar 9 menunjukkan bahwa mayoritas mahasiswa tetap termotivasi untuk berpartisipasi dalam kuliah jarak jauh. Mahasiswa Angkatan 2017 berjumlah 24 orang menyatakan setuju dan 16 orang menyatakan sangat setuju. Mahasiswa Angkatan 2018 berjumlah 27 orang menyatakan setuju dan 20 orang menyatakan sangat setuju. Mahasiswa Angkatan 2019 berjumlah 21 orang menyatakan setuju dan 18 orang menyatakan sangat setuju. Pada pembelajaran jarak jauh ini, mahasiswa tetap termotivasi untuk berpartisipasi aktif dalam kuliah. Pembelajaran dengan menggunakan platform LMS, google classroom, zoom meeting, dan lain-lain tetap bisa membantu mahasiswa untuk aktif selama kuliah. Mahasiswa berkesempatan untuk diskusi, mengajukan pertanyaan, menyampaikan pendapat melalui platform yang digunakan.

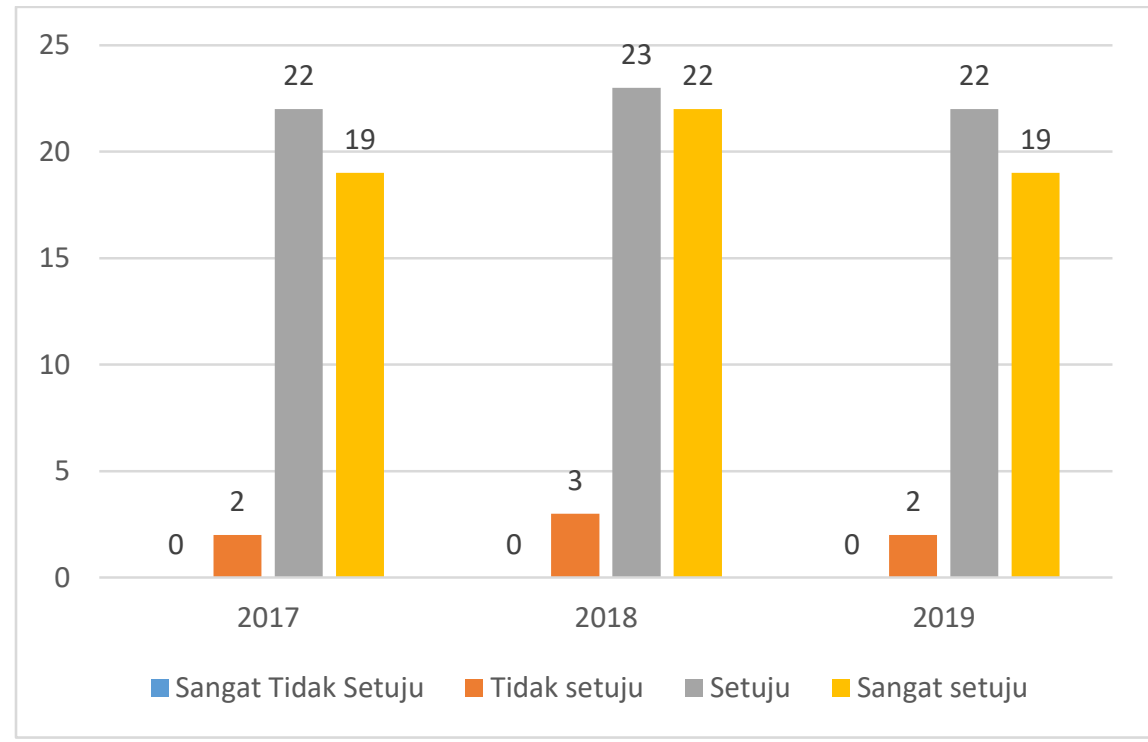

Gambar 10. Diagram Mahasiswa Dapat Menyelesaikan Proyek dan Mendapatkan Nilai yang Diinginkan 
Berdasarkan gambar 10 dapat diketahui bahwa mayoritas mahasiswa dapat menyelesaikan proyek tugas dan mendapatkan nilai yang diinginkan bahkan ketika orang lain berpikir tidak bisa. Mahasiswa Angkatan 2017 berjumlah 22 orang menyatakan setuju dan 19 orang menyatakan sangat setuju. Mahasiswa Angkatan 2018 berjumlah 23 orang menyatakan setuju dan 22 orang menyatakan sangat setuju. Mahasiswa Angkatan 2019 berjumlah 22 orang menyatakan setuju dan 19 orang menyatakan sangat setuju. Mahasiswa optimis menyelesaikan tugas dan mendapatkan nilai yang dinginkan pada pembelajaran jarak jauh. Belajar dari rumah tidak membuat mahasiswa pesimis dalam mengerjakan tugas. Mahasiswa mempunyai waktu yang leluasa dalam mengakses materi, mengerjakan tugas, dan upgrade pengetahuan lainnya. Aspek fasilitas belajar mendukung dalam mengerjakan proyek yang ditugaskan pada mahasiswa.

Hasil penelitian ini menujukkan bahwa efikasi diri mahasiswa pada masa pembelajaran jarak jauh ini baik. Mahasiswa mempunyai keyakinan dapat mempelajari semua materi kuliah dengan usaha keras walaupun materi sulit. Mahasiswa mempunyai sikap positif terhadap kuliah. Mahasiswa yakin dengan berjalannya waktu akan semakin mampu mempelajari materi kuliah. Mahasiswa yakin dapat terus belajar walaupun terganggu di dalam kelas dan dapat mencapai tujuan akademik yang diinginkan dengan berusaha keras. Mahasiswa yakin mampu mengembangkan cara-cara kreatif untuk mengatasi stres yang terjadi di kuliah dan tetap termotivasi untuk berpartisipasi aktif dalam kuliah. Mahasiswa dapat menyelesaikan proyek dan mendapatkan nilai yang diinginkan. Oleh sebab itu, efikasi diri mahasiswa Prodi Pendidikan Akuntansi pada masa pembelajaran jarak jauh adalah baik.

Hasil penelitian ini relevan dengan penelitian yang dilakukan oleh Prior et al., (2016) bahwa efikasi diri memberikan efek positif pada keterlibatan teman sebaya, interaksi learning management system (LMS) dan interaksi penyelenggara pembelajaran. Efikasi diri dan motivasi belajar merupakan faktor yang dapat mempengaruhi hasil belajar (Monika \& Adman, 2017) (Seto et al., 2020). Efikasi diri yang baik akan mempengaruhi hasil belajar mahasiswa. Hal itu sejalan dengan penelitian Seto et al., (2020) yang menjelaskan bahwa efikasi diri mempunyai pengaruh positif terhadap hasil belajar. Pembelajaran jarak jauh memberikan fleksibilitas dalam pembelajarannya serta mampu meningkatkan kemandirian belajar dan motivasi belajar mahasiswa (Sadikin \& Hamidah, 2019). Pembelajaran ini juga memberikan manfaat berupa meningkatnya minat dan motivasi, keberanian mengemukakan gagasan dan pertanyaan (Sadikin \& Hamidah, 2019).

Hasil penelitian yang dilakukan Yorganci (2017) menunjukkan bahwa tingkat efikasi diri siswa secara umum sedang dan sebagian besar siswa memiliki sikap positif terhadap penggunaan m-learning. Terdapat perbedaan tingkat efikasi diri siswa terhadap m-learning yaitu berdasarkan pada pengalaman pembelajaran seluler sebelumnya dan jurusan akademik. Kemudian siswa laki-laki memiliki perspektif yang lebih positif terhadap penggunaan $m$ learning daripada siswa perempuan. Hasil penelitian tersebut relevan dengan hasil penelitian 
ini yaitu efikasi diri mahasiswa Prodi Pendidikan Akuntansi baik. Namun hasil penelitian ini tidak mengukur perbedaan gender terhadap aktivitas pembelajaran jarak jauh.

(Sun \& Rueda, 2012) melakukan penelitian dengan hasil yaitu aktivitas dan media online dapat meningkatkan keterlibatan emosional dalam pembelajaran online, meskipun hal itu tidak selalu meningkatkan keterlibatan perilaku atau kognitif. Pendidik perlu menawarkan strategi kepada siswa untuk meningkatkan regulasi diri mereka dalam lingkungan pendidikan jarak jauh. Keterlibatan emosional ini relevan dengan hasil penelitian ini yaitu mahasiswa dapat mempertahankan sikap positif terhadap kuliah bahkan ketika ketegangan muncul. Sikap positif perlu dipertahan kan dalam pembelajaran jarak jauh karena mahasiswa dan dosen tidak bisa bertatap muka secara langsung dalam pembelajaran. Mahasiswa harus menguasai emosi agar dapat belajar mandiri dan aktif saat pembelajaran jarak jauh.

Efikasi diri terdiri dari 4 komponen yaitu kinerja akademik, pengembangan pengetahuan dan keterampilan, interaksi sosial dengan fakultas, dan mengatasi stres akademik (S Schmitz, 2013). Hasil penelitian yang dilakukan Seto et al., (2020) menunjukkan bahwa efikasi diri mempunyai pengaruh positif terhadap hasil belajar. Hal tersebut menunjukkan bahwa efikasi diri erat kaitannya dengan kinerja akademik mahasiswa. Kemudian efikasi diri erat kaitannya dengan tingkat stress akademik. Hasil penelitian (Utami et al., 2020) menunjukkan bahwa efikasi diri berpengaruh secara signifikan terhadap tingkat stres akademik mahasiswa selama pandemi Covid19 periode April-Mei 2020 dimana efikasi diri menunjukkan kontribusi yang bersifat negative, artinya ketika efikasi diri meningkat maka stres akademik akan menurun. Efikasi diri pada masa pembelajaran jarak jauh perlu ditanamkan di diri mahasiswa. Hal tersebut agar mahasiswa mempunyai rasa optimis, minat, motivasi, dan tidak mudah menyerah dalam mencapai tujuan akademik. Pembelajaran jarak jauh juga memberikan kesempatan bagi mahasiswa untuk belajar hal baru melalui media pembelajaran yang berbeda dengan tatap muka. Sehingga mahasiswa mempunyai pengalaman belajar yang baru.

\section{SIMPULAN}

Berdasarkan hasil penelitian ini, dapat dikatakan bahwa efikasi diri mahasiswa Prodi Pendidikan Akuntansi adalah baik. Efikasi diri dalam pembelajaran pada mahasiswa Prodi Pendidikan Akuntansi menunjukkan bahwa mahasiswa mempunyai keyakinan dapat mempelajari semua materi kuliah dengan usaha keras walaupun materi sulit. Mahasiswa mempunyai sikap positif terhadap kuliah. Mahasiswa yakin dengan berjalannya waktu akan semakin mampu mempelajari materi kuliah. Mahasiswa yakin dapat terus belajar walaupun terganggu di dalam kelas dan dapat mencapai tujuan akademik yang diinginkan dengan berusaha keras. Mahasiswa yakin mampu mengembangkan cara-cara kreatif untuk mengatasi stres yang terjadi di kuliah dan tetap termotivasi untuk berpartisipasi aktif dalam kuliah. Mahasiswa dapat menyelesaikan proyek dan mendapatkan nilai yang diinginkan. Implikasi hasil penelitian ini adalah perkuliahan di desain 
menjadi perkuliahan yang interaktif antara dosen dan mahasiswa, materi kuliah yang didesain mudah dipahami, media pembelajaran yang kreatif, dan forum diskusi yang aktif. Kemudian hasil penelitian ini diharapkan dapat memberikan masukan untuk pengembangan teori efikasi diri khususnya efikasi diri mahasiswa pada pembelajaran jarak jauh. Penelitian ini hanya di Prodi Pendidikan Akuntansi sehingga belum bisa memberikan kesimpulan secara umum mengenai efikasi diri mahasiswa. Penelitian selanjutnya diharapkan dapat mengembangkan model pembelajaran yang dapat meningkatkan efikasi diri mahasiswa.

\section{DAFTAR PUSTAKA}

Alqurashi, E. (2016). Self-Efficacy In Online Learning Environments: A Literature Review. Contemporary Issues in Education Research (CIER), 9(1), 45-52. https://doi.org/10.19030/cier.v9i1.9549

Bandura, A. (1993). Perceived self-efficacy in cognitive development and functioning. Educational psychologist. In Educational psychologist (Vol. 28, Issue 2, pp. 117-148).

Bandura, A. (2010). Self-efficacy -Bandura. The Corsini Encyclopedia of Psychology, 1-3.

Cucinotta, D., \& Vanelli, M. (2020). WHO declares COVID-19 a pandemic. Acta Biomedica, 91(1), 157-160. https://doi.org/10.23750/abm.v91i1.9397

Gunawan; Ni Made Yeni Suranti; Fathoroni. (2020). Variations of Models and Learning Platforms for Prospective Teachers During the COVID-19 Pandemic Period. 1(2), 75-94.

Hariani, P. P., \& Wastuti, S. N. Y. (2020). Pemanfaatan E-Learning Pada Pembelajaran Jarak Jauh di Masa Pandemi Covid-19. Biblio Couns : Jurnal Kajian Konseling Dan Pendidikan, 3(1), 41-49. https://doi.org/10.30596/bibliocouns.v3i2.4656

Monika, M., \& Adman, A. (2017). Peran Efikasi Diri Dan Motivasi Belajar Dalam Meningkatkan Hasil Belajar Siswa Sekolah Menengah Kejuruan. Jurnal Pendidikan Manajemen Perkantoran, 2(2), 109. https://doi.org/10.17509/jpm.v2i2.8111

Peechapol, C., Na-songkhla, J., Sujiva, S., \& Luangsodsai, A. (n.d.). An Exploration of Factors Influencing Self-Efficacy in Online Learning : A Systematic Review. 64-86.

Prawiyogi, A. G., Purwanugraha, A., Fakhry, G., \& Firmansyah, M. (2020). Efektifitas Pembelajaran Jarak Jauh Terhadap Pembelajaran Siswa di SDIT Cendekia Purwakarta. Jurnal Pendidikan Dasar, 11(01), 94-101.

Prior, D. D., Mazanov, J., Meacheam, D., Heaslip, G., \& Hanson, J. (2016a). Attitude, digital literacy and self efficacy: Flow-on effects for online learning behavior. Internet and Higher Education, 29, 91-97. https://doi.org/10.1016/j.iheduc.2016.01.001

Prior, D. D., Mazanov, J., Meacheam, D., Heaslip, G., \& Hanson, J. (2016b). Attitude, digital 
literacy and self efficacy: Flow-on effects for online learning behavior. Internet and Higher Education. https://doi.org/10.1016/j.iheduc.2016.01.001

Rafsanjani, A. I. (2019). Kebijakan Pendidikan di Era New Normal. Permenkes Nomor 7 Tahun 2019 Tentang Kesehatan Lingkungan Rumah Sakit, 8(5), 55.

S Schmitz, G. (2013). Development and Validation of a Student Self-efficacy Scale. Journal of Nursing \& Care, 02(01), 1-6. https://doi.org/10.4172/2167-1168.1000126

Sadikin, A., \& Hamidah, A. (2019). Pembelajaran Daring di Tengah Wabah Covid-19. TARBAWY: Indonesian Journal of Islamic Education, 6(2), 187-192. https://doi.org/10.17509/t.v6i2.20887

Schunk, D. H. (1991). Self-Efficacy and Academic Motivation. Educational Psychologist, 26(3-4), 207-231. https://doi.org/10.1080/00461520.1991.9653133

Seto, S. B., Suryani, L., Goretty, M., Bantas, D., Studi, P., Matematika, P., Flores, U., \& Artikel, I. (2020). ANALISIS EFIKASI DIRI DAN HASIL BELAJAR BERBASIS E-LEARNING. 1, $147-152$.

Sun, J. C. Y., \& Rueda, R. (2012). Situational interest, computer self-efficacy and self-regulation: Their impact on student engagement in distance education. British Journal of Educational Technology, 43(2), 191-204. https://doi.org/10.1111/j.1467-8535.2010.01157.x

Utami, S., Rufaidah, A., \& Nisa, A. (2020). Kontribusi self-efficacy terhadap stres akademik mahasiswa selama pandemi Covid-19 periode April-Mei 2020 Universitas Indraprasta PGRI $\left.123{ }^{*}\right)$. Electronic) Pusat Kajian BK Unindra-IKI, 20(1), 20-27. https://doi.org/10.26539/teraputik.41294

Widiyono, A. (2020). Efektifitas Perkuliahan Daring (Online) pada Mahasiswa PGSD di Saat Pandemi Covid 19. Jurnal Pendidikan, 8(2), 169-177. https://doi.org/10.36232/pendidikan.v8i2.458

Yokoyama, S. (2019). Academic Self-Efficacy and Academic Performance in Online Learning: A Mini Review. 9(January), 1-4. https://doi.org/10.3389/fpsyg.2018.02794

Yorganci, S. (2017). Investigating Students' Self-Efficacy and Attitudes Towards the Use of Mobile Learning. Journal of Education and Practice, 8(6), 181-185. 